mł. bryg. dr inż. Joanna RAKOWSKA ${ }^{\mathbf{1}}$

mgr inż. Katarzyna RADWAN ${ }^{2}$

mgr inż. Zuzanna ŚLOSORZ ${ }^{3}$

Przyjęty/Accepted/Принята: 14.06 .2013 ;

Zrecenzowany/Reviewed/Рецензирована: 21.03.2014;

Opublikowany/Published/Oпубликована: 30.06 .2014 ;

\title{
BADANIA PORÓWNAWCZE WYNIKÓW ANALIZY GRANULOMETRYCZNEJ ZIAREN PROSZKU GAŚNICZEGO PRZEPROWADZONEJ RÓŻNYMI METODAMI
}

\author{
Comparative Study of the Results of the Extinguishing Powder Grain Size \\ Analysis Carried out by Different Methods
}

\section{Сравнительные исследования результатов гранулометрического анализа частиц огнетушащего порошка, проведённого различными методами}

\begin{abstract}
Abstrakt
Cel: Analiza granulometryczna jest istotnym czynnikiem, za pomocą którego między innymi ocenia się prawidłowość przebiegu wielu procesów technologicznych, a wyniki tej oceny stanowią często główny element optymalizacji parametrów pracy urządzeń. Z tego powodu, w wielu gałęziach przemysłu, bardzo ważne jest stosowanie najbardziej dokładnych metod oceny składu granulometrycznego materiałów. Celem pracy jest porównanie rezultatów rozkładu wielkości cząstek proszku gaśniczego uzyskanego różnymi metodami. Projekt i metody: Istnieją różne techniki analizy wielkości cząstek. Obecnie najczęściej stosowane techniki pomiarów wielkości cząstek substancji stałych to analiza sitowa, metoda dynamicznego rozpraszania światła, statyczne techniki rozpraszania światła oraz mikroskopia. Każda z metoda ma swoje zalety, ale również wady. W badaniach zastosowano przesiewacz powietrzny Alpine LS 200, laboratoryjny przesiewacz wibracyjny typu WSU, analizator ANALYSETTE 22 MicroTec plus oraz analizator HELOS \& RODOS. Wyniki: W artykule przedstawiono porównanie wyników rozkładu wielkości cząstek proszku gaśniczego typu ABC, otrzymane tradycyjną metodą analizy sitowej, techniką dyfrakcji laserowej oraz metodą optyczno-elektroniczną. Analiza obrazu cząstek nie uwzględnia tych samych parametrów agregatów co analiza sitowa. W przypadku pomiaru wielkości ziaren wykorzystującego analizę obrazu próbki nie jest uwzględniany pomiar masy, podczas gdy analiza sitowa przedstawia odniesienie do procentowego udziału masy cząstek danej wielkości. Wyniki analizy metodami optycznymi są często przedstawiane jako procentowy udział ilości cząstek określonej wielkości lub procentowy udział agregatów o danej powierzchni.

Wnioski: Wyniki składu ziarnowego otrzymane różnymi metodami są odmienne. Jest to spowodowane zastosowaniem aparatów, których techniki wykorzystują pomiar różnych właściwości fizycznych badanego materiału. Istotne jest więc podawanie wyników wraz z informacją o stosowanej metodzie i typie aparatury. Korelacja wyników otrzymanych metodą sitową z rezultatami analizy obrazu zależy od kształtu badanych cząstek. Konwersja wyników osiągniętych jedną metodą do innej techniki dla różnych materiałów wymaga rozważenia wpływu odpowiednich parametrów fizycznych, takich jak gęstość próbki czy właściwości optyczne.
\end{abstract}

Słowa kluczowe: proszek gaśniczy, wielkość ziarna, analiza sitowa, dyfrakcja laserowa

Typ artykułu: oryginalny artykuł naukowy

\section{Abstract}

Purpose: A particle size analysis is an essential parameter used for assessing the correctness of numerous technological processes. Its results constitute a key element in the assessment and optimization of operational parameters of devices. Due to this fact, in

${ }^{1}$ Centrum Naukowo-Badawcze Ochrony Przeciwpożarowej im. Józefa Tuliszkowskiego - Państwowy Instytut Badawczy, Nadwiślańska 213, Józefów, Polska, jrakowska@cnbop.pl / Scientific and Research Centre for Fire Protection - National Research Institute, Poland; wkład procentowy / percentage contribution $-40 \%$

${ }^{2}$ Centrum Naukowo-Badawcze Ochrony Przeciwpożarowej im. Józefa Tuliszkowskiego - Państwowy Instytut Badawczy / Scientific and Research Centre for Fire Protection - National Research Institute, Poland; wkład procentowy / percentage contribution - 40\%

${ }^{3}$ Centrum Naukowo-Badawcze Ochrony Przeciwpożarowej im. Józefa Tuliszkowskiego - Państwowy Instytut Badawczy / Scientific and Research Centre for Fire Protection - National Research Institute, Poland; wkład procentowy / percentage contribution - 20\% 
various industry branches, it is very important to apply the most accurate ways of assessing the grain size composition of materials. The aim of this study is to compare the results of the particle size distribution of dry powder obtained through various methods.

Project and methods: There are various techniques of particle size analysis. Currently, the most frequently used techniques for particle size measurements are: sieve analysis, dynamic light scattering, static light scattering and microscopy. Each method has advantages, but also disadvantages. The research was conducted with the application of the following instruments: air jet sieve Alpine LS 200, vibratory sieve shaker type WSU, Laser-Particle-Sizer ANALYSETTE 22 MicroTec plus, analyser HELOS \& RODOS and analyser IPS UA.

Results: The paper presents a comparison of a particle size distribution of extinguishing powder measured by the traditional sieve analysis, the laser diffraction methods and optical-electronic methods. The image analysis of particles does not measure the same size of aggregates as the sieve analysis. The size of particles determined by the image analysis does not measure mass, whereas the sieve analysis is presented in relation to the percent cumulative mass. The results are often presented as the percentage share of particles or aggregates of the given area. The correlation of sieve analysis to the image methods is dependent on the particles shape. A conversion of results achieved with one method to the results of another method for different materials requires consideration of appropriate physical parameters such as density of samples or optical properties.

Conclusions: The results obtained by these methods were not identical for the reason that each of them applied other physical parameter in measurement. As the effect of differences in measuring methods the results of the analysis of the same sample are various. It is important to present the results together with information on the methods and the type of used equipment. The correlation of sieve analysis with image methods is dependent on particles shape. A conversion of results achieved with one method to results of other method for different materials requires consideration of appropriate physical parameters such as density of samples or optical properties.

Keywords: extinguishing powder, particle size, sieve analysis, laser diffraction

Type of article: original scientific article

\section{Аннотация}

Цель: Гранулометрический анализ является важным фактором, при помощи которого, в частности, оценивают правильность хода многих технологических процессов, а результаты этой оценки часто составляют главный элемент оптимизации параметров работы устройств. В связи с тем, во многих отраслях промышленности, очень важным является использование наиболее точных методов оценки гранулометрического состава материалов. Целью работы является сравнение результатов распределения размеров частиц огнетушащего порошка, полученных различными методами.

Проект и методы: Существуют различные технологии анализа размеров частиц. В настоящее время наиболее часто используемые технологии измерения размеров частиц твёрдых веществ это: ситовой анализ, динамическое рассеивание света, статические технологии рассеивания света и микроскопия. Каждый метод имеет свои преимущества, а также недостатки. В исследованиях была использована воздухоструйная просеивающая машина Alpine LS 200, лабораторная просеивающая вибрационная машина типа WSU, анализатор ANALYSETTE 22 MicroTec plus, а также анализатор HELOS \& RODOS.

Результаты: В статье представлены сравнение результатов распределения размеров частиц огнетушащего порошка типа $\mathrm{ABC}$, полученных традиционным методом ситового анализа, технологией лазерной дифракции и оптико-электронным методом. Анализ образа частиц не учитывает тех самых параметров агрегатов, что ситовый анализ. В случае измерения размера частиц с использованием анализа изображения образца измерения массы не учитываются, в то время, как ситовой анализ представляет отношение к процентному участию массы частиц данного размера. Результаты анализа оптическими методами часто представлены как процентное содержание частиц определённого размера, или процентное содержание агрегатов конкретной поверхности.

Выводы: Результаты определения гранулометрического состава частиц, полученные разными методами, отличаются друг от друга. Это связано с использованием устройств, технологии которых используют измерения различных физических свойств исследуемого материала. Поэтому очень важным есть, представлять результаты вместе с информацией о примененном методе и типе оборудования. Соотношение результатов, полученных ситовым методом и путём анализа изображений зависит от формы исследуемых частиц. Преобразование результатов, полученных с использованием одного метода к другой технологии для разных материалов, требует рассмотрения влияния соответствующих физических параметров, таких как плотность образца или оптические свойства.

Ключевые слова: огнетушащий порошок, размер частиц, ситовой анализ, лазерная дифракция Вид статьи: оригинальная научная статья

\section{Wprowadzenie}

Pożary są niekontrolowanym procesem spalania występującym w miejscu do tego nieprzeznaczonym. Ich wielkość i liczba zdarzeń jest uzależniona od świadomości ludności, zagrożeń wynikających z uprzemysłowienia oraz panujących warunków klimatycznych w danym regionie. $\mathrm{W}$ akcjach ratowniczych do gaszenia pożarów wykorzystuje się środki gaśnicze dostosowane do rodzaju palącego się materiału oraz panujących warunków. Ze względu na szeroki zakres stosowania oraz wysoką efektywność działania proszki gaśnicze odgrywają istotną rolę w gaszeniu pożarów [1].
Mianem proszku gaśniczego nazywa się drobno zmielone, niepalne związki węglanowe lub fosforanowe otoczone hydrofobową błoną, których zadaniem jest inhibicja reakcji chemicznych zachodzących w strefie spalania oraz odizolowanie dostępu tlenu od płonącego ciała. Podczas użycia proszków węglanowych (typu BC) dodatkowo wydzielany jest dwutlenek węgla obniżający stężenia utleniacza w strefie spalania oraz chłodzący strefę gazową. Z kolei proszki fosforanowe wykazują zdolność wytwarzania szklistej powłoki pokrywającej powierzchnię gaszonego ciała stałego (mechanizm izolujący). Proszki gaśnicze stosowane są do gaszenia pożarów różnej wielkości, zarówno do pożarów w zarodku, jak i poża- 
rów rozlanych cieczy lub urządzeń technologicznych [1]. Skuteczność działania proszków gaśniczych wynika z ich składu chemicznego oraz stopnia rozdrobnienia ziarna. Zależnie od przeznaczenia, w recepturze proszków gaśniczych najczęściej stosowane są sole metali na bazie węglanów, fosforanów, soli potasowych, chlorowych, mocznikowych. Natomiast dyspersja ziaren proszku wpływa na wielkość powierzchni reakcji w płomieniu oraz możliwość dotarcia proszku do strefy spalania.

Wyróżniamy kilka metod badania i oceny wielkości ziaren. Każdy ze sposobów pomiaru uziarnienia opiera się na analizie w ściśle określonych warunkach, sprecyzowanych dla danego procesu różnych właściwości fizycznych (gęstości, przezroczystości, ładunku elektrycznego). W rezultacie, dla tych samych materiałów, przy wykorzystaniu różnych metod badawczych, uzyskuje się niejednolite wyniki lub ich brak, gdy efekt badania nie mieści się w zakresie pomiarowym. W celu zminimalizowania błędów pomiarowych powstających podczas badań warto rygorystycznie przestrzegać sposobu przygotowywania próbek, gdyż ma on bezpośredni wpływ na wynik końcowy.

Do najczęściej stosowanych metod badania uziarnienia należą metody sitowe i metody optyczne [2].

Zastosowanie metody sitowej jest powszechnie wykorzystywanym sposobem rozdzielania materiałów sypkich. Urządzeniami stosowanymi do selekcjonowania ziaren są przesiewacze, w skład których wchodzą sita o różnych wielkościach oczek, dobierane odpowiednio dla badanego materiału. Analizę sitową prowadzi się, umieszczając określoną ilość badanej mieszaniny na sicie, przez którego otwory część materiału zostaje przesiana (przesiew, podziarno), a pozostała część zatrzymana na jego powierzchni (odsiew, nadziarno). Wynik pomiaru z użyciem sit zależy od czasu analizy oraz siły wytrząsania lub podciśnienia w komorze przesiewacza. Rezultat badań określony jest tylko przez drugi, maksymalny wymiar cząstki i nie zawiera informacji na temat dokładnej wielkości analizowanego ziarna. Wyniki pomiaru dla większych ziaren obarczone są większym błędem. Proces przesiewania można prowadzić zarówno na sucho, jak i na mokro [3].

$\mathrm{W}$ metodach optycznych pomiaru wielkości cząstek stałych wykorzystuje się:

- dyfrakcję Fraunhofera

Metoda dyfrakcji laserowej bazuje na zjawiskach dyfrakcji oraz interferencji fal świetlnych. Zjawisko dyfrakcji zachodzi, kiedy fala przechodzi przez szczelinę lub omija obiekt, tworząc źródło promieniście rozchodzących się fal świetlnych, które ulegają wzmocnieniu lub wygaszeniu (interferencja). Natężenie oświetlenia dla poszczególnych kątów odchylenia świadczy o rozkładzie wielkości cząstek. Podczas badania zakłada się, że wszystkie cząstki są niereaktywnymi kulami, losowo układającymi się w zawiesinie. Wynik dyfrakcji otrzymywany jest w procentach objętościowych. W porównaniu do wcześniej opisywanych metod sitowych ten sposób pomiaru jest szybki i wymaga małej ilości próbki potrzebnej do badania. Rezultaty tej metody różnią się od wyników uzyskanych metodami przesiewania $\mathrm{z}$ powodu wykorzystywania innych wielkości fizycznych oraz założeń, m.in. jednakowej gęstości ziaren, kulistości ich kształtu [2, 6, 7].

- pomiar w ognisku optycznym

Zasada pomiaru polega na pomiarze rozproszenia światła lub pomiarze natężenia światła odbitego przez cząstki przechodzące przez miejsce, gdzie znajdują się ogniska układów optycznych: oświetlającego i odbierającego promieniowanie [4].

- pomiarw równoległej wiązce promieniowania w świetle przechodzącym

Zasada pomiaru polega na utworzeniu dużych płaszczyzn pomiarowych o jednakowej czułości w każdym ich punkcie. Cząstka przechodząca przez płaszczyznę pomiarową wywołuje rozproszenie strumienia promieniowania proporcjonalne do wymiaru cząstki [4].

Celem artykułu jest porównanie wyników metod analizy uziarnienia proszku gaśniczego $\mathrm{ABC}$, wykonanych różnymi metodami (metoda sitowa, dyfrakcja laserowa, metoda optyczno-elektroniczna).

\section{Materiały}

Do badań zastosowano proszek gaśniczy ABC o gęstości nasypowej 0,93 g/ml. Głównymi składnikami proszku są:

- fosforan jednoamonowy - 21,5\%

- siarczan amonowy - 74,0\%

Preparat jest zabezpieczony warstwą hydrofobową na bazie silikonu, powodującą większą odporność na wchłanianie wilgoci i zapobiegająca zbrylaniu. Proszek przeznaczony jest do gaszenia pożarów grupy A, B i C [5].

\section{Metody badań}

\subsection{Przesiewacz sitowy ALPINE 200 LS}

Za pomocą urządzenia Alpine 200 LS firmy HOSOKAWA ALPINE (Niemcy) można przeprowadzić analizę rozmiarów cząstek materiałów sypkich i kontroli jakości produktu. Budowę urządzenia Alpine 200 LS przedstawiono na ryc. 1.

Podczas pomiaru wielkości cząstek w komorze panuje podciśnienie. Wchodzące powietrze przepływa przez obrotową dyszę szczelinową do komory produktu, w której następuje proces fluidyzacji, a następnie wraz z podziarnem przechodzi przez otwory sita. Na wielkość podciśnienia w komorze przesiewania wpływają siła ssąca oraz opór tkaniny sita. Po przesianiu frakcji na bębnie sitowym pozostaje nadziarno. Kolejne pomiary wykonuje się na sitach o coraz większych oczkach.

Badanie wykonano na trzech sitach; 40, 63 i $125 \mu \mathrm{m}$. Analizę wykonano dla $40 \mathrm{~g}$ badanego proszku gaśniczego, rozpoczynając pomiar od sita $40 \mu \mathrm{m}$. Czas pomiaru na jednym sicie wynosił $5 \mathrm{~min}$.

\subsection{Laboratoryjny przesiewacz wibracyjny typu WSU (Zakład Doświadczalny Poznań)}

Zasada metody polega na rozdzieleniu badanej próbki na frakcje przez przesianie na zestawie sit kontrolnych, a następnie ustaleniu procentowego udziału poszczegól- 


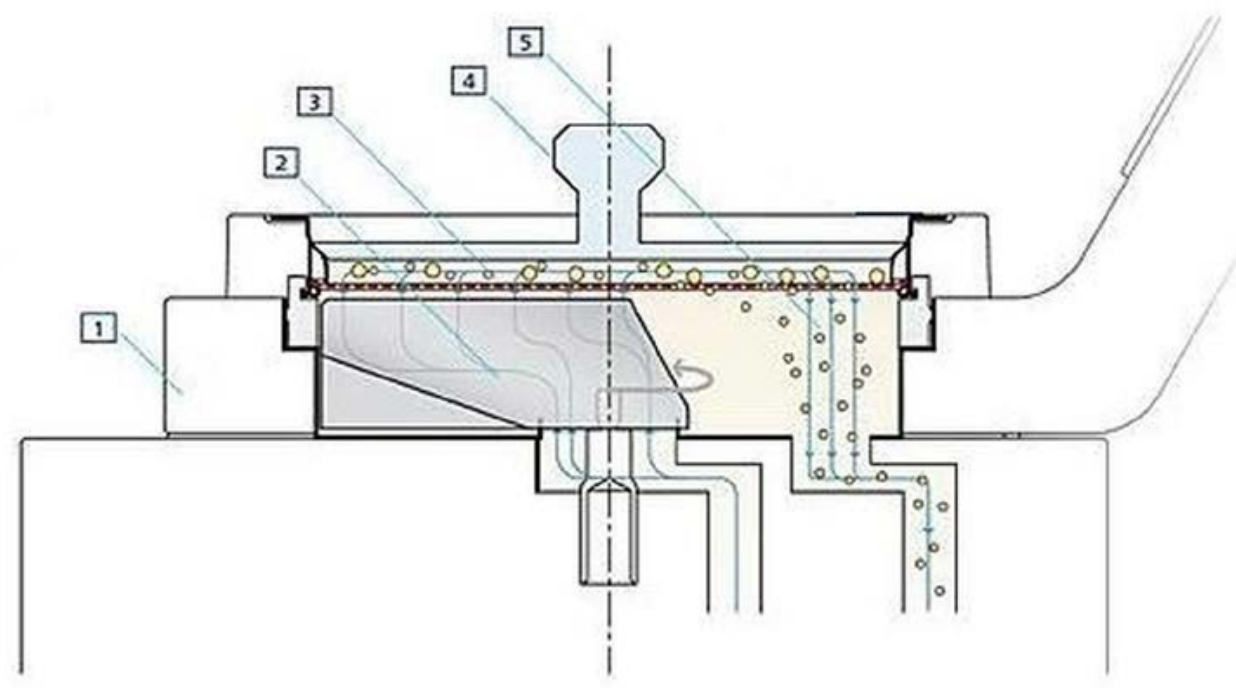

1. Obudowa (Housing)

2. Dysza (Nozzle)

3. Sito (Analysis sieve)
4. Pokrywa (Cover)

5. Przepływ powietrza i przesiewu (Air and fines flow)

Ryc. 1. Schemat przesiewacza Alpine 200 LS [8]

Fig. 1 Scheme of Air jet sieve 200 LS

nych frakcji w badanej próbce. Badanie wykonano na wstrząsarce laboratoryjnej typu WSU z zestawem sit 40, 63 i $125 \mu \mathrm{m}$, metodą na sucho. Próbkę przesiewano przez $5 \mathrm{~min}$.

\subsection{HELOS Laser Sensor}

Miernik laserowy wielkości cząstek firmy Sympatec (Niemcy) zbudowany jest z czujnika HELOS oraz rozsiewacza RODOS. Za pomocą urządzenia można badać zarówno próbki suche, jak i mokre, np. proszki, zawiesiny, emulsje lub substancje w postaci aerozolu [9].

Czujniki dyfrakcji laserowej stosowane w mierniku pracują $\mathrm{w}$ równoległym strumieniu promienia laserowego. Światło ugięte pod kątem $\theta$ jest przenoszone na pierścień detektora o promieniu $\mathrm{r}$ - dzięki soczewkom Fouriera - niezależnie od pozycji cząstki. W połączeniu z adaptowaną średnicą promienia świetlnego uzyskuje się dla wszystkich zakresów pomiarowych dużą przestrzeń roboczą. W urządzeniu zastosowano laser HeNe o długości fali $632,8 \mathrm{~nm}$ z rezonatorem i filtrami, którego zadaniem jest stworzenie prawie (niemal) płaskiej fali dla oświetlenia cząstek. Zasadę działania lasera przedstawiono na ryc. 2 [9].

Badania dla analizowanego proszku przeprowadzono przy zastosowaniu suchej próbki.

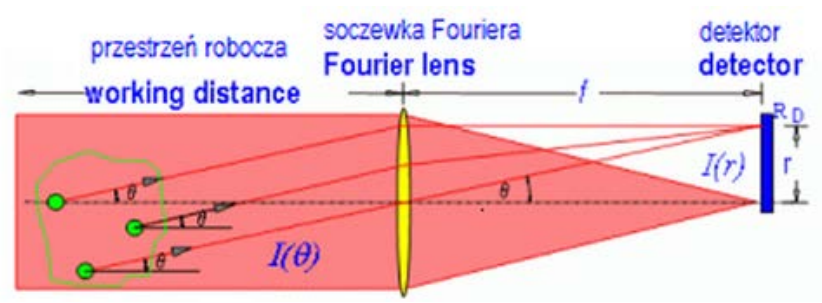

Ryc. 2. Zasada działania lasera HELOS Laser Sensor [9]

Fig. 2. Principle of operating of the HELOS Laser Sensor [9]

\subsection{ANALYSETTE 22 MicroTec plus}

Do badań z użyciem laserowej metody pomiaru cząstek wykorzystano miernik ANALYSETTE 22 MicroTec plus firmy Fritsch (Niemcy) o zakresie pomiarowym 0,08 $2000 \mu \mathrm{m}$. Urządzenie zbudowane jest $\mathrm{z}$ półprzewodnikowego lasera zielonego oraz lasera podczerwonego. Załamanie długofalowego czerwonego strumienia laserowego umożliwia uzyskanie dokładności pomiarowej dla dużych cząstek. W przypadku przejścia do pomiaru drobnych cząstek następuje przesunięcie detektora krótkofalowego zielonego strumienia laserowego i źródła światła laserowego - cela pomiarowa pozostaje w miejscu (ryc. 3, ryc. 4). Oba lasery można automatycznie i niezależnie od siebie optymalnie ustawiać poprzez poprzeczne przesunięcie.

Badania $\mathrm{z}$ wykorzystaniem miernika ANALYSETTE 22 MicroTec plus wykonano, posługując się zasadą dyfrakcji laserowej - fizyczną zasadą elektromagnetycznego rozpraszania się fal podczas analizy wielkości cząstek po ich dostarczeniu do analizatora. Podczas badania analizowana cząstka jest oświetlana strumieniem lasera. Przez częściowe odchylenie światła laserowego powstaje charakterystyczny pierścieniowy rozkład intensywności, który jest mierzony przez detektor. Na podstawie odległości pomiędzy pierścieniami obliczana jest wielkość cząstki. Małe cząstki wytwarzają pierścienie szeroko rozstawione, duże natomiast wytwarzają pierścienie leżące ciasno obok siebie. ANALYSETTE 22 MicroTec jest przeznaczony do analizy procesu na sucho cząstek stałych w strumieniu powietrza bądź na mokro w postaci zawiesiny w zamkniętym obiegu cieczy pomiarowej [10]. Badania proszku gaśniczego zostały wykonane metodą na mokro, jako nośnika badanego materiału użyto izopropanolu. 


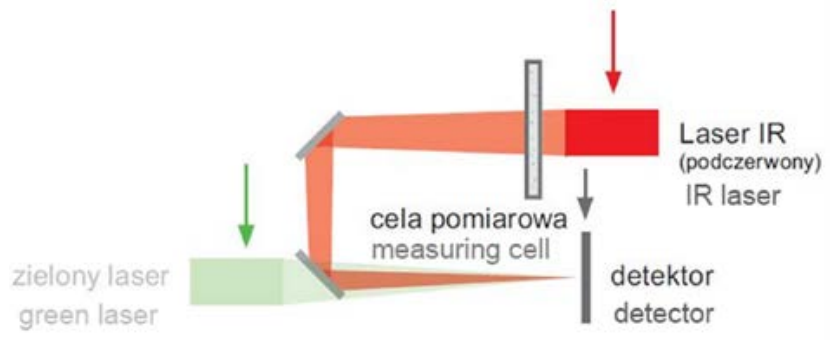

Ryc. 3. Układ pomiarowy dla górnego zakresu wielkości cząstek [9]

Fig. 3. Measurement system for the lower particle size range [9]

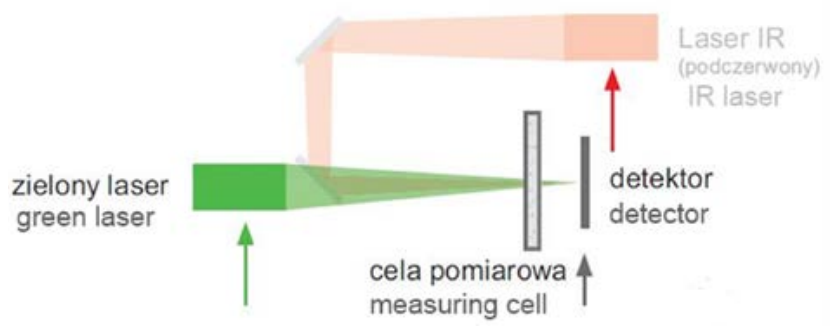

Ryc. 4 Układ pomiarowy dla dolnego zakresu wielkości czastek [10]

Fig. 4 Measurement system for the upper particle size range [10]

\subsection{Analizator IPS UA}

Optyczno-elektroniczna metoda pomiarowa stosowana przez firmę Kamika (Polska) wykorzystuje sposób liczenia i mierzenia ziaren w równoległej wiązce promieniowania. W tej metodzie można stosować dowolne źródła promieniowania, a przestrzeń pomiarowa jest ograniczona tylko konstrukcją układów optycznych. Taki sposób pomiaru uziarnienia może zastąpić pomiar z wykorzystaniem sit mechanicznych, symulując ich postać i dając tożsame wyniki [4].

Do dozowania materiałów ziarnistych w tej metodzie używa się głównie powietrza, w przypadku zawiesin można używać wody lub roztworów wodnych. Na ryc. 5 przedstawiono czujnik pomiarowy, składający się ze źródła promieniowania (1) (fotodioda emitująca światło w zakresie bliskiej podczerwieni), które oświetla układ optyczny A, formujący równoległą wiązkę światła (2) ograniczoną szczeliną o grubości do kilkuset $\mu \mathrm{m}$. Wiązka światła (2) aż do układu optycznego B tworzy przestrzeń pomiarową. Układ optyczny B ogniskuje wiązkę na fotoelemencie (3). Gdy w przestrzeni pomiarowej brak jakichkolwiek cząstek, to na wyjściu (4) z przedwzmacniacza płynie prąd stały wynikający z oświetlenia fotodiody. Gdy w przestrzeni pomiarowej pojawią się cząstki porównywalne lub większe od grubości szczeliny, to na skutek rozproszenia światła następuje zmiana napięcia na wyjściu (4) w postaci impulsu. Dla cząstek submikronowych zjawisko rozpraszania światła zostaje zmodyfikowane przez zjawisko dyfrakcji. W przestrzeni pomiarowej ze względu na przepływ powietrza lub wody ziarno jest jednoznacznie usytuowane i zawsze porusza się swym najmniejszym wymiarem i największym przekrojem wzdłuż kierunku ruchu [4].

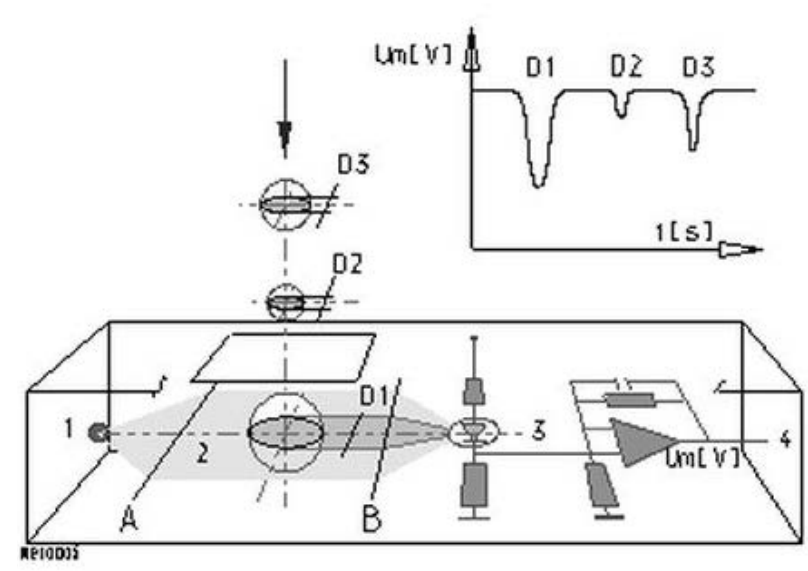

Ryc. 5. Pomiar w równoległej wiązce promieniowania [4] Fig. 5. Measurement in parallel beam [4]

Zasada pomiaru $\mathrm{w}$ równoległej wiązce promieniowania polega na utworzeniu dużych płaszczyzn pomiarowych o jednakowej czułości w każdym ich punkcie, ograniczonych tylko rozstawieniem i średnicą układów optycznych. Cząstka przechodząca przez płaszczyznę pomiarową wywołuje rozproszenie strumienia promieniowania proporcjonalne do wymiaru cząstki [4].

\section{Wyniki i dyskusja}

Przykładowy rozkład wielkości ziaren analizowanego proszku gaśniczego ABC metodą dyfrakcji laserowej przy zastosowaniu miernika ANALYSETTE 22 MicroTec plus, przedstawiono na ryc. 6 . Na ryc. 7 przedstawiono rozkład wielkości ziaren proszku otrzymany za pomocą miernika HELOS, natomiast na ryc. 8 zaprezentowano rezultaty uzyskane za pomocą analizatora optyczno-elektronicznego IPS UA.

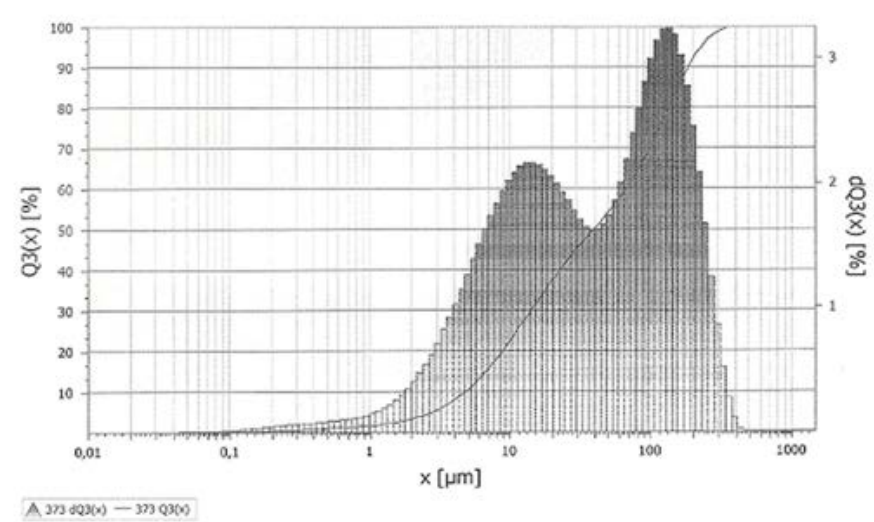

Ryc. 6. Rozkład wielkości ziaren proszku gaśniczego ABC otrzymany metodą dyfrakcji laserowej na mokro (analizator ANALYSETTE 22 MicroTec plus); Q3 - objętość sumaryczna, $\mathrm{x}$ - średnica ziarna

Fig. 6. Particle size distribution of extinguishing powder

ABC obtained by laser diffraction method - wet dispersion (analyser ANALYSETTE 22 MicroTec plus); Q3 - qumulative distribution, $\mathrm{x}$ - particle size 


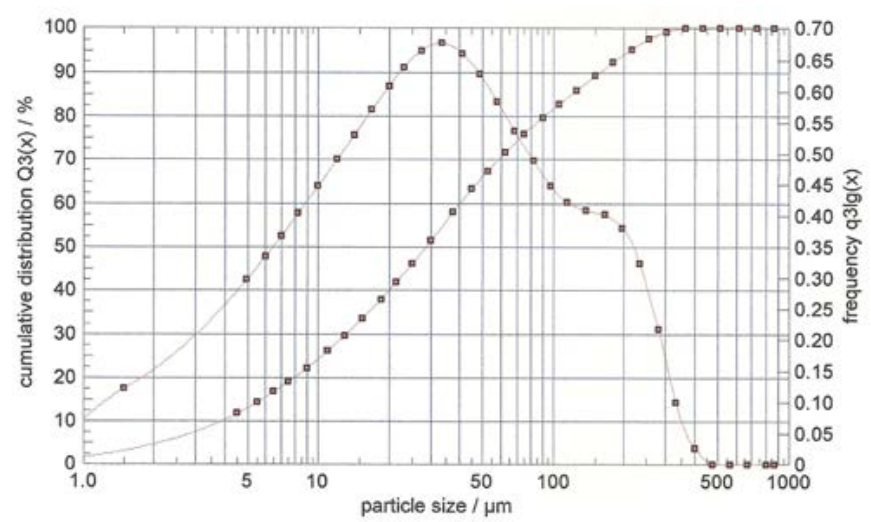

Ryc. 7. Rozkład wielkości ziaren proszku gaśniczego ABC otrzymany metodą dyfrakcji laserowej na sucho (analizator HELOS \& RODOS)

Fig. 7. Particle size distribution of extinguishing powder $A B C$ obtained by laser diffraction method - dry dispersion (analyser HELOS \& RODOS)

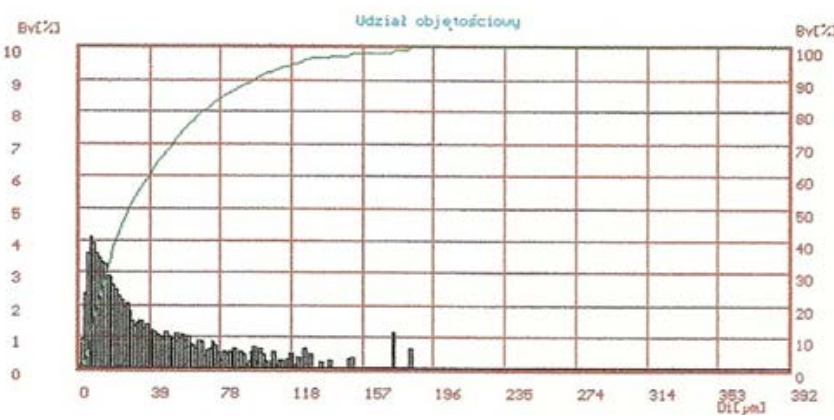

Ryc. 8. Rozkład wielkości ziaren proszku gaśniczego ABC otrzymany metodą optyczno-elektroniczną (analizator IPS UA); Bv - udział objętościowy, Di - średnica ziarna

Fig. 8. Particle size distribution of extinguishing powder $A B C$ obtained by optical-electronic method (analyser IPS UA); $\mathrm{Bv}$ - volume participation, $\mathrm{Di}$ - particle size

Wyniki rozpatrywano dla trzech frakcji: $>40 \mu \mathrm{m},>63$ $\mu \mathrm{m}$ i $>125 \mu \mathrm{m}$, zgodnie $\mathrm{z}$ wymaganiami normy PN-EN 615 „Ochrona przeciwpożarowa. Środki gaśnicze. Wymagania techniczne dotyczące proszków (innych niż do gaszenia pożarów grupy D)" [11]. Takie wielkości ziaren są istotne ze względu na właściwości proszku gaśniczego, ponieważ na skuteczność proszku składa się nie tylko jego działanie na konkretny pożar, ale także takie cechy, które umożliwiają mu dotarcie do strefy spalania, m.in. struktura ziarnistości i kształt ziaren.

Ze względu na sposób zachowania się cząstek proszków w płomieniu można wyróżnić ich dwa rodzaje:

1. Cząstki niewykazujące zmian wielkości po wprowadzeniu do płomienia, (proszki tradycyjne - węglanowe, fosforanowe, chlorkowe, siarczanowe).

2. Cząstki rozpadające się w płomieniu $\mathrm{z}$ wytworzeniem submikronowych drobin ciała stałego, np. proszki mocznikowo-węglanowe.

Proszki rozpadające się w płomieniu zwiększają swą powierzchnię właściwą, co jest korzystne z punktu widzenia zarówno inhibicji heterofazowej, jak i homofazowej, dlatego są one znacznie skuteczniejsze niż proszki z grupy pierwszej. Po rozpadzie, w przypadku graniczne- go rozmiaru cząstki, takiego, że zapewnione jest całkowite odparowanie, różnice $\mathrm{w}$ skuteczności działania będą wynikały jedynie $\mathrm{z}$ różnic $\mathrm{w}$ łatwości pirolizy.

Przebieg reakcji rozkładu typowego składnika proszku gaśniczego opisują następujące reakcje [12]:

$$
\begin{aligned}
& \mathrm{Na}_{2} \mathrm{CO}_{3} \rightarrow \mathrm{Na}_{2} \mathrm{O}+\mathrm{CO}_{2} \uparrow \\
& \mathrm{Na}_{2} \mathrm{O} \rightarrow \mathrm{Na}_{2} \mathrm{O} \uparrow \\
& \mathrm{Na}_{2} \mathrm{O}+\mathrm{H}_{2} \mathrm{O} \rightarrow 2 \mathrm{NaOH} \\
& \mathrm{NaOH}+\mathrm{H}^{\cdot} \rightarrow \mathrm{Na}^{*}+\mathrm{H}_{2} \mathrm{O} \\
& \mathrm{NaOH}+\cdot \mathrm{OH} \rightarrow \mathrm{NaO}+\mathrm{H}_{2} \mathrm{O}
\end{aligned}
$$$$
2 \mathrm{NaHCO} 3 \rightarrow \mathrm{Na} 2 \mathrm{CO} 3+\mathrm{CO} 2 \uparrow+\mathrm{H} 2 \mathrm{O} \uparrow
$$

Przedstawione rozważania, co do mechanizmu działania gaśniczego proszków, wskazują na bardzo duży wpływ stopnia rozdrobnienia na skuteczność gaśniczą. Ze wzrostem stopnia rozdrobnienia wzrasta skuteczność gaśnicza zarówno z punktu widzenia inhibicji heterofazowej (większa powierzchnia inhibitora $w$ jednostce objętości reagentów), jak i obu możliwych mechanizmów inhibicji homofazowej (zwiększa się powierzchnia wymiany ciepła, a zatem stopień odparowania i rozkładu). $Z$ drugiej strony, nie można jednak dowolnie zwiększać stopnia rozdrobnienia proszków, gdyż wówczas pogarszają się jego walory użytkowe: odporność na zbrylanie, na działanie wilgoci, zdolność przepływu przez przewody instalacji [13], zasięg rzutu itp. Istnieje więc pewien optymalny skład granulometryczny, zapewniający dobre walory użytkowe, a jednocześnie dużą skuteczność gaśniczą. Niekorzystna jest obecność frakcji o średnicach poniżej $10 \mu \mathrm{m}$. Zazwyczaj frakcja o średnicach od 20 do $60 \mu \mathrm{m}$ powinna stanowić $60 \div 80 \%$ wagi całości. Jednocześnie z punktu widzenia własności dynamicznych proszku (zdolność do transportu przewodami, zasięg rzutu) korzystna jest obecność $10 \div 15 \%$ frakcji o średnicach $100 \div 200 \mu \mathrm{m}$ [14]. Podane zakresy wielkości cząstek mają jedynie charakter orientacyjny i zależnie od składu chemicznego i struktury proszku mogą ulegać znacznym wahaniom. Te najważniejsze parametry wpływające na zdolność proszku do transportu $\mathrm{w}$ fazie fluidalnej powinny być niezmienne $\mathrm{w}$ czasie.

Na ryc. 9 przedstawiono porównanie wyników pomiarów wielkości ziaren wykonanych różnymi metodami.

Na podstawie przeprowadzonych badań potwierdzono rozbieżności wyników pomiędzy zastosowanymi metodami. Różnice w otrzymanych rezultatach pomiarów wynikają z zastosowania metod, które wykorzystują różne właściwości badanego materiału. Przy zastosowaniu metody sitowej, na powierzchni sit oraz urządzeniu przesiewającym może pozostawać pewna niewielka ilość pyłu, która ma wpływ na wynik analizy (masę tej frakcji). W związku z tym należy dbać, aby do analizy zawsze używać czystych sit. Podczas przesiewania na sucho różnice powstają również $\mathrm{w}$ wyniku rozpylania najdrobniejszych frakcji podczas przesiewania. Dodatkowo podczas analizy sitowej istotny jest tylko jeden wymiar cząstek, czego konsekwencja jest zawyżanie udziału frakcji drobnej wskutek przechodzenia przez sito większych ziaren o kształcie np. wrzecionowatym. W rezultacie dla odmiennych kształtów 
lub też poszczególnych frakcji ziaren otrzymuje się wyniki obarczone różnymi niepewnościami pomiaru.

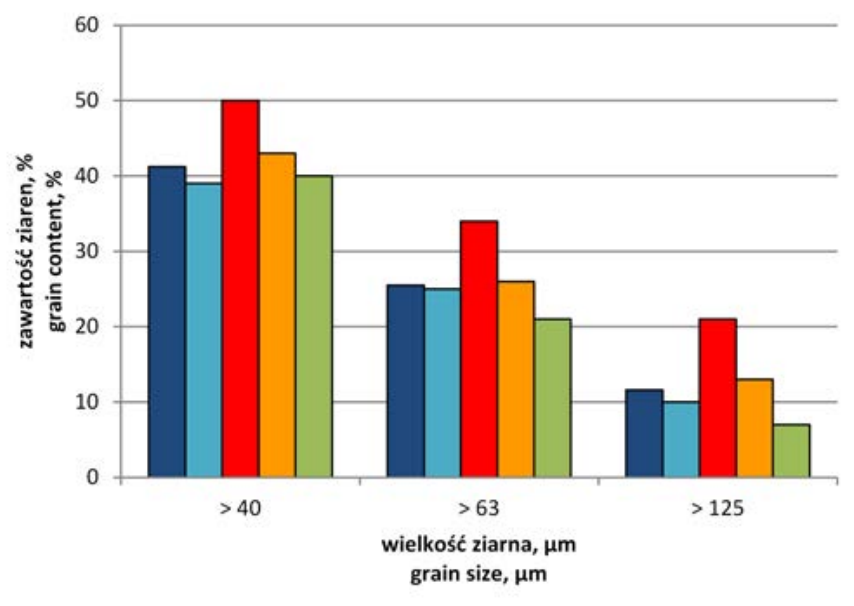

Ryc. 9. Porównanie rozkładu wielkości ziaren proszku otrzymanych różnymi metodami pomiarowymi: przesiewacz powietrzny, laboratoryjny przesiewacz wibracyjny, metoda dyfrakcyjna na mokro, metoda dyfrakcyjna na sucho, metoda optyczno-elektroniczna

Fig. 9. Comparison of the powder particle size distribution obtained by different measurement methods: air jet sieve,

vibratory sieve shaker, laser diffraction method - wet dispersion, laser diffraction method - dry dispersion, opticalelectronic method

W analizie dyfrakcyjnej wielkość cząstek określana jest poprzez światło odbite od cząstki i gdy cząstka nie jest kulista, wynik pomiaru nie zawsze pokrywa się z wymiarem rzeczywistym. Wynik pomiaru zależy również od właściwości optycznych cząstki. Metoda opracowana została do cząstek kulistych, przeźroczystych i jednorodnych [15], jednak teoretyczne i doświadczalne badania wykazały, że dla cząstek niesferycznych stosowanie teorii Mie może prowadzić do znacznych błędów, szczególnie przy dużych kątach rozpraszania [16]. Gdy wielkość cząstek jest znacznie większa niż długość fali padającego światła o współczynniku załamania znacząco różnym od otaczającego środowiska, większość światła rozproszona jest w kierunku do przodu pod małym kątem w stosunku do kierunku propagacji wiązki padającej. Przy takich warunkach, teoria dyfrakcji Fraunhofera odpowiednio opisuje rozpraszania zjawiska dla większości zastosowań $[17,18]$.

Na wynik analizy ma również wpływ fakt czy zastosowano metodę na sucho czy też na mokro. Substancje stosowane jako nośniki w metodzie na mokro mogą reagować $\mathrm{z}$ analizowanym materiałem, wpływając na wynik ostateczny analizy. W przypadku analizy przy zastosowaniu dyfrakcji laserowej na mokro (miernik ANALYSETTE 22 MicroTec) jako nośnika użyto izopropanolu, który może niszczyć zabezpieczenie hydrofobowe proszku gaśniczego, zmieniając właściwości i strukturę analizowanego medium, a w konsekwencji otrzymane wyniki nie będą odzwierciedlać rzeczywistej wielkości ziaren proszku.

Również różny sposób przygotowania próbek do analiz może odgrywać rolę w zróżnicowaniu wyników. Do analizy metodą dyfrakcji laserowej używa się stosunkowo niewielkiej ilości badanego materiału (ok. 1 g). Tak mała próbka może nie być reprezentatywna w stosunku do całej partii materiału. W przypadku dyfrakcji laserowej dodatkowo niewielka ilość najmniejszego ziarna może być pomijana ze względu na to, że pierścienie dyfrakcyjne tej frakcji mogą być poza detektorem urządzenia [2].

Ważnym elementem urządzeń optycznych do pomiaru składu ziarnowego materiałów jest źródło światła. Długość fali promieniowania diod laserowych i emitujących bliską podczerwień są zbliżone do siebie (600-900 nm). Dla układów pomiarowych wykorzystujących optykę geometryczną wymagana jest jednorodność natężenia strumienia promieniowania, ponieważ to zapewnia jednorodną czułość w danym obszarze pomiarowym. Trudno jest uzyskać laserowy strumień promieniowania o jednakowym natężeniu w każdym jego punkcie. Pomiar cząstki w różnym miejscu szczeliny metodą światła rozproszonego daje różne wyniki pomiarów. W związku z tym przy użyciu dyfrakcji laserowej wyniki mogą się różnić. Wynika to $\mathrm{z}$ geometrii promieniowania diody laserowej oraz ustawienia diody względem szczeliny. Promieniowanie diod IR jest bardziej równomierne niż diod laserowych [4].

\section{Podsumowanie}

Tradycyjne metody analiz granulometrycznych są powoli wypierane przez metody elektroniczne np. dyfrakcji laserowej. Zaletami analizy składu ziarnowego z wykorzystaniem metod optycznych są bardzo krótkie czasy pomiaru, automatyzacja pomiaru, wysoka precyzja oraz powtarzalność procesu.

Przeprowadzone badania wykazały, że stosowane metody pomiarowe dotyczące wielkości ziarna mają wiele ograniczeń i zakres ich stosowania jest bardzo selektywny. Porównywanie danych $\mathrm{z}$ różnych metod jest $\mathrm{w}$ wielu przypadkach niemożliwe ze względu na błędy, jakimi każda z nich może być obarczona. Porównanie wyników otrzymanych różnymi metodami może mieć jedynie charakter orientacyjny.

W wielu przypadkach zastosowanie konkretnej metody wynika ze względów ekonomicznych. Gdy wyniki muszą być uzyskane w bardzo krótkim czasie i badań wykonuje się dużo, opłacalne jest wykorzystywanie szybkich, chociaż drogich aparatów.

Nowoczesne proszki gaśnicze powinny charakteryzować się wysoką efektywnością gaśniczą wynikającą z właściwości chemicznych oraz stopnia rozdrobnienia materiału. Optymalny skład granulometryczny każdego proszku może być więc nieco inny.

Obecność ziaren o rozwiniętej powierzchni jest korzystniejsza ze względu na szybki przebieg reakcji inhibitujących, natomiast mniej korzystna ze względu na większą zagęszczalność proszku, co ma istotne znaczenie podczas transportu proszku wewnątrz urządzenia gaśniczego.

Kształt ziaren wynika przede wszystkim ze składu chemicznego proszku wymuszającego określoną budowę krystalograficzną ziaren oraz przebiegu procesu technologicznego, w którym drobiny są wytwarzane. 


\section{Literatura}

1. Wilczkowski S., Środki gaśnicze, SA PSP, Kraków, 1999.

2. Płoskonka D., Różnice w wynikach analiz uziarnienia przeprowadzonych różnymi metodami, Instytut Geografii i Przestrzennego Zagospodarowania, Polska Akademia Nauk, Vol. 12, 2010, pp. 79-85.

3. Ryżak M., Walczak R. T., Niewczas J., Porównanie rozkładu granulometrycznego czastek glebowych metoda dyfrakcji laserowej i metoda sedymentacyjnq, „Acta Agrophysica” Vol. 4 Issue 2, 2004, pp. 509-518.

4. Kamińska D., Kamiński S., Zastosowanie przyrzq̨ów KAMIKA do badania rozkładu wielkości czqstek pylu węglowego i popiolu, jak również pomiaru zawartości pylu w spalinach, ASH - IV International Scientific and Practical Workshop, Moskwa, 2012.

5. PN-EN 2:1998/A1:2006P Podział pożarów.

6. Heuer M., Leschonski K., Results obtained with a new Instrument for the Measurement of Particle Size Distributions from Diffraction Patterns; Vol. 2, 1985, pp. 7-13.

7. Khanam T., Nurur Rahman M., Rajendran A., Kariwala V., Asundi A.K., Accurate size measurement of needle-shaped particles using digital holography, „Chemical Engineering Science”, Vol. 66 Issue 12, 2011, pp. 2699-2706.

8. http://www.airjetsieve.com, (27-03-2013 r.).

9. http://www.sympatec.com, (27-03-2013 r.).

10. Laserowe mierniki cząstek, materiały reklamowe firmy Fritsch.

11. PN-EN 615:2009E Ochrona przeciwpożarowa. Środki gaśnicze. Wymagania techniczne dotyczące proszków (innych niż do gaszenia pożarów grupy D).

12. Fu X., Huck D., Makein L., Armstrong B., Willen U., Freeman T., Effect of particle shape and size on flow properties of lactose powders, Particuology Vol. 10, 2012, pp. 203-208.

13. Andersson B., Blomqvist P., Experimental study of thermal breakdown products from halogenated extinguishing agents, Fire Safety Journal, Vol. 46 Issue 3, 2011, pp. 104-115.

14. Mizerski A., Sobolewski M., Środki gaśnicze, SGSP, Warszawa 1997.

15. Bech H., Leder A., Simultaneous determination of particle size and refractive index by time-resolved Mie scattering,
Optik - International Journal for Light and Electron Optics, Vol. 121 Issue 20, 2010, pp. 1815-1823.

16. Kalashnikova O.V., Sokolik I.N., Modeling the radiative properties of nonspherical soil-derived mineral aerosols, Journal of Quantitative Spectroscopy and Radiative Transfer Vol. 87 Issue 2, 2004, pp. 137-166.

17. H.C. van de Hulst, Light Scattering by Small Particles, Wiley, New York (1969).

18. Hecht E., Optics (2nd edn.), Addison-Wesley, Genève, 1987.

Badania wykonano w ramach działalności statutowej, nr tematu 035/BC/CNBOP-PIB/MNiSW/ 2013-2015.

dr inż. Joanna Rakowska ukończyła studia na Wydziale Inżynierii Materiałowej Politechniki Warszawskiej. Stopień doktora nauk technicznych w zakresie technologii chemicznej uzyskała na Wydziale Technologii Chemicznej Politechniki Poznańskiej. Specjalność - technologia preparatów chemicznych stosowanych przez jednostki ratowniczo-gaśnicze. Zastępca kierownika w Zespole Laboratoriów Badań Chemicznych i Pożarowych CNBOP-PIB.

mgr inż. Katarzyna Radwan w roku 2007 ukończyła studia na Wydziale Matematyczno-Przyrodniczym (kierunek Chemia) Akademii Świętokrzyskiej w Kielcach. W CNBOP-PIB pracuje w Zespole Laboratoriów Badań Chemicznych i Pożarowych. Specjalność - technologia preparatów gaśniczych.

mgr inż. Zuzanna Ślosorz w roku 2011 ukończyła studia na Wydziale Technologii Chemicznej Politechniki Poznańskiej. W CNBOP-PIB w Zespole Laboratoriów Badań Chemicznych i Pożarowych zajmuje się badaniami środków powierzchniowo czynnych. 